\title{
Przemysław Gut
}

The John Paul II Catholic University of Lublin, Poland

ORCID: 0000-0001-6329-0373

e-mail: dedo@kul.lublin.pl

\section{The Cartesian Theory of Emotions and Early Modern Philosophy*}

DOI: http://dx.doi.org/10.12775/RF.2018.031

Most historical literature presents the early modern period of philosophy as the Age of Reason. What is more, it is claimed that the most preeminent philosophers of the $17^{\text {th }}$ and $18^{\text {th }}$ centuries were not interested in doing research in any spheres of human life other than reason as they a priori assumed that reason itself is all that is needed to live and act well. Recently, however, claims have been made that this description of what is largely understood as the Modern Age or the Age of Enlightenment, although apparently well justifiable, cannot be maintained under closer scrutiny. ${ }^{1}$ It is true that reason was considered by most of the thinkers of

* The article was supported by a research grant by the National Science Centre, Poland (UMO2012/07/B/HS1/01959).

List of Abbreviations

AT - refers to the standard Franco-Latin edition of Descartes by C. Adam and P. Tannery, OEuvres de Descartes, 12 vols., revd. edn. Paris: J. Vrin/CNRS, 196476; CSM - refers to the English translation by J. Cottingham, R. Stoothoff, and D. Murdoch, The Philosophical Writings of Descartes, vols. 1 and 2. Cambridge: Cambridge University Press, 1984; CSMK - refers to the English translation by J. Cottingham, R. Stoothoff, D. Murdoch, and A. Kenny, The Philosophical Writings of Descartes, vol. 3: The Correspondence. Cambridge: Cambridge University Press, 1991. References to the Passions of the Soul will be given by article number followed by page reference to CSM and AT editions.

1 See: Henry Vyverberg, Human Nature, Cultural Diversity, and the French Enlightenment, Oxford-New York: Oxford University Press, 1989, 36 ff.; Donald Rutherford (ed.), The Cambridge Companion to Early Modern Philosophy, Cambridge: Cambridge University Press, 2017, 1-10. 
the early modern period the only faculty able to provide a human being with complete knowledge about reality. It is also true that, in general, they believed in the practical power of reason and maintained that with the help of reason a human being can overcome possible dangers. Even so, to say that the noteworthy thinkers of the $17^{\text {th }}$ and $18^{\text {th }}$ centuries had no understanding of aspects of human life other than reason is going too far. In the Encyclopédie, on the one hand, we can read that reason is the utmost human power but, on the other hand, that in order to fulfill one's goals effectively, it is necessary to take emotions into account as they determine the direction and force of our activity.

In this paper, I am going to present the Cartesian theory of emotions. The founder of modernity initiated deep changes in the way we understand emotions: their origin and effect on the human being. It is his doctrine of emotions that provided the basis for most discussions on issues concerning emotions in the $17^{\text {th }}$ and $18^{\text {th }}$ centuries and became a reference point for most theories of emotion created in modern times.

The Cartesian theory of emotions covers a wide scope of reflections, starting from the question of what emotions are and what their proximate and remote causes might be, through the issue of the so-called basic emotions to the question of the possibility of emotion control. Surprisingly, the Cartesian analyses pose almost all basic questions explored in the modern research on emotions.

René Descartes was not the first thinker to systematically formulate the most important questions concerning emotions. From time immemorial, philosophers have pointed out that human behavior is not determined by beliefs (knowledge) only, but also by emotions. ${ }^{2}$ Hence, the view that in order to answer the question why people act the way they do it is necessary to take into consideration not only cognitive factors (what people think), but also affective ones (what they desire and feel) has been quite common. Nevertheless, the preponderant view, advocated mainly by Plato and Stoics and later developed by the thinkers of the Middle Ages, was that emotions, regardless of being part of human nature, have on the whole negative impact on people and their actions both in terms

2 See: Susan James, Passion and Action: The Emotions in Seventeenth-Century Philosophy, Oxford: Oxford University Press, 1997; Richard Sorabji, Emotion and the Peace of Mind: From Stoic Agitation to Christian Temptation, Oxford: Oxford University Press, 2000; Simo Knuuttila, Emotions in Ancient and Medieval Philosophy, Oxford-New York: Oxford University Press, 2004. 
of rationality and morality. ${ }^{3}$ Many arguments were used to justify this general belief. Some of them derive from the assumption widely held by many thinkers from antiquity and the Middle Ages that the powers of the soul (mind) have a hierarchical structure and from the belief expressed by some medieval philosophers that sensu stricto only two of the powers are the powers of the human soul, namely, reason (intellect) and will, while emotions (feelings) belong to the sensory and corporal part of the human being. ${ }^{4}$ Other convictions of this type had their source in the religious and intellectual culture of the Middle Ages which included the notable notion of sin identified with emotion, passion, and affect. ${ }^{5}$

Descartes was one of the first thinkers who cast doubt on the view that contrasts emotions with reason and human nature in a radical way. He strongly argued that emotions are not negative by nature; they are not as such powers that make people act badly. On the contrary, emotions provide the basis for beneficial and rational behaviors (see: Passions 137, CSM I: 376; AT XI 430; Passions 211, CSM I: 403; AT XI 486). ${ }^{6}$ Descartes did not deny that some emotions can be unpleasant or painful and that too powerful a flow of emotions can cause genuinely disastrous and destructive actions. It is worth noting that Descartes claimed that it is possible to prevent inappropriate emotions. By means of an adequate organization of emotions and by learning the mechanisms that govern emotions we can effectively control our emotional life. What is important here is that the goal of this control is not a suppression of emotions or Stoic emotionlessness, but rather achieving balance and such management of emotions that they can serve the purpose of practical goals in human life (see: Passions 212, CSM I: 404; AT XI 488; Letter to Princess Elizabeth $3^{\text {rd }}$ November 1645, CSMK $276 \mathrm{ff}$, AT IV $\left.330 \mathrm{ff}\right)$.

Descartes presented his stance on emotions (passions) in a separate treatise entitled The Passions of the Soul (Les Passions de l'âme) written in

3 It is important to emphasize that this view, though dominant, was not really common. In antiquity, certain thinkers such as Aristotle held the opposite view, namely, that emotions are not something that is in principle undesirable. The discussion on whether emotions (passions, affects) influence humans in a positive or negative way continues until today.

4 See: Stefan Swieżawski, Święty Tomasz na nowo odczytany, Kraków: Znak, 1983, $181 \mathrm{ff}$.

5 See: Jacques Le Goff, Człowiek średniowiecza, Warszawa-Gdańsk: Wydawnictwo Marabut, 1996.

6 See: Lilli Alanen, Descartes's Concept of Mind, Cambridge, MA: Harvard University Press, 2003, 190 ff.; Desmond Clarke, Descartes's Theory of Mind, Oxford: Oxford University Press, 2005, 134; Amy Schmitter, "How to engineer a human being: passions and functional explanation in Descartes," in J. Broughton and J. Carriero (eds.), A Companion to Descartes, Malden: Blackwell, 2008, 426-444; Lisa Shapiro, "Descartes' Passions of the Soul and the Union of Mind and Body," Archiv für Geschichte der Philosophie 85, no. 3, (2003): 211-248. 
1646 and published in Paris in 1649.7 The treatise consists of three parts. The first part talks about the nature of emotions and their causes. The second one elaborates on six basic (primitive) emotions. The third one is about derivative emotions and the way of controlling them. The main goal of the treatise is posing important questions belonging mainly to the psychological order. In the letter preceding the treatise, Descartes stated explicitly that his intention was 'to explain the passions only as a natural philosopher, and not as a rhetorician or even as a moral philosopher' (CSM I: 327; AT XI 236). This remark is extremely significant. Firstly, it brings out one of the most important differences between the Cartesian treatment of emotions and the views that were predominant in the Middle Ages and the Renaissance. While Descartes focused on the analysis of emotions, most of the medieval and Renaissance thinkers tended to elaborate on the use and role of emotions. Secondly, this note points out that research into emotions is to be done according to the rules laid down in the Principles of Philosophy, which means that it has the same basis as two other branches of science, namely, mechanics and medicine. ${ }^{8}$ Thirdly, this remark expresses Descartes' dissent from such an approach to emotions that led to formulate rash conclusions and judgments about emotions without thorough research into their psychological and physiological nature. Descartes, by contrast, held the view that it is impossible to properly understand and explore emotions until one understands the nature of the faculties of the mind, the physiology of the human body and the consequences of the substantial union between the body and the mind. ${ }^{9}$

Descartes expected that the new approach towards emotions that he offered would discourage many readers, especially those looking for a sort of advisory book on how to handle emotions. He was deeply convinced, however, that the papers on emotions that had been published so far were at best common sense reflections, but not science. This is what Descartes wrote at the beginning of his treatise:

The defects of the sciences we have from the ancients are nowhere more apparent than in their writings on the passions. The topic, about which knowledge has always been keenly sought, does not seem to be one of the more difficult to investigate since everyone feels passions in himself and so has no need to look elsewhere for observations to establish their nature. And yet the teachings of the ancients about passions are so meagre and for the most part implausible that I cannot hope to approach the truth

7 Important remarks on emotions can also be found in letters exchanged by Descartes and Princess Elisabeth.

8 Stephen Gaukroger, "Descartes' Theory of the Passions," in J. Cottingham (ed.), Descartes, Oxford: Oxford University Press, 1998, 218.

9 See: ibidem, $218 \mathrm{ff}$. 
except by departing from the paths they followed. That is why I shall be obliged to write just as if I were considering a topic that no one had dealt with before me. (Passions 1, CSM I: 328; AT XI 328)

In the light of modern analyses, this opinion is obviously unjustifiable. But even so, undeniably, in the times of Descartes, his treatise was innovative and groundbreaking. It introduced transparency to the branch of philosophical research which seemed to be very elusive. It sketched new perspectives for research on emotions. It pointed out that the scientific approach, i.e. referring to natural causes, is justifiable and may turn out to be profitable. ${ }^{10}$

What is the context of the Cartesian analyses of emotions? Three contexts seem most relevant. The first one is the research on the human body done by Descartes from the mid-forties of the $17^{\text {th }}$ century. The treatise Passions of the Soul is closely linked to this research. Under its influence Descartes most probably decided to take into consideration physiological factors when analyzing emotions. The second context, also extremely important while thinking of the Cartesian view of emotions, is the distinctly human relation of the mind and body, he assumed. From this assumption, it follows that emotions cannot be comprehended in any other way but with reference to both the mind and the body. In the Principles of Philosophy, Descartes wrote that beside the states that are connected only with the mind, such as thinking or willing, and states that are connected only with the body, such as shape, motion or divisibility, 'we also experience within ourselves certain other things which must not be referred either to the mind alone or to the body alone' as they follow "from the close and intimate union of our mind with the body" (CSM I: 209; AT VIIIA 23). This means that any inquiry into emotions must take into account the unity of the body and the mind. The third context, also noteworthy, is the Cartesian ethical doctrine. According to this doctrine, harmful emotions constitute the main obstacle in living and acting well. The more competent in handling them we are, the more virtuous we become, and the more joy may we have in our emotional endowment (see Passions 212, CSM I: 404; AT XI 488). ${ }^{11}$

\section{2}

Descartes starts his detailed analyses by introducing a distinction between two principal kinds of thoughts: 'some being actions of the soul

10 See: Desmond Clarke, Descartes's Theory of Mind, 108; Stephen Gaukroger, "Descartes' Theory of the Passions", 219.

11 See: John Cottingham, Descartes, Oxford: Blackwell, 1986, 152-156. 
and others its passions' (Passions 17, CSM I: 335; AT XI 342). He defines passions as any sort of perceptions that are not caused by the soul: it is 'not our soul which makes them such as they are, and the soul always receives them from things that are represented by them' (Passions 17, CSM I: 335; AT XI 342). Actions are understood as volitions, 'for we experience them as proceeding directly from our soul and as seeming to depend on it alone' (Passions 17, CSM I: 335; AT XI 342). Passions can be divided into those caused by the soul and those derivative from the body. The latter can fall either into the category of those that do not depend on nerves, e.g. imaginings, and those that are conveyed to the soul by means of nerves. Passions caused by the body and conveyed by means of nerves can be divided into the following categories: a) perceptions that we refer to things outside us, which are called sensations; b) perceptions that we refer to our body or to its part that are known by internal sensation, such as hunger or pain, and c) perceptions that we refer to our soul itself, which are called passions (emotions) in the strict sense. Volitions can fall into the following categories a) 'the actions of the soul which terminate in the soul itself, as when we will love God or, generally speaking, to apply our mind to some object which is not material' and 'the actions which terminate in our body, as when our merely willing to walk has the consequence that our legs move or walk' (Passions 18, CSM I: 335; AT XI 343). There are also perceptions that have their root in the soul itself. These are the perceptions of our volitions, acts of reflection, or purely intellectual perceptions. This division is depicted by the diagram below:

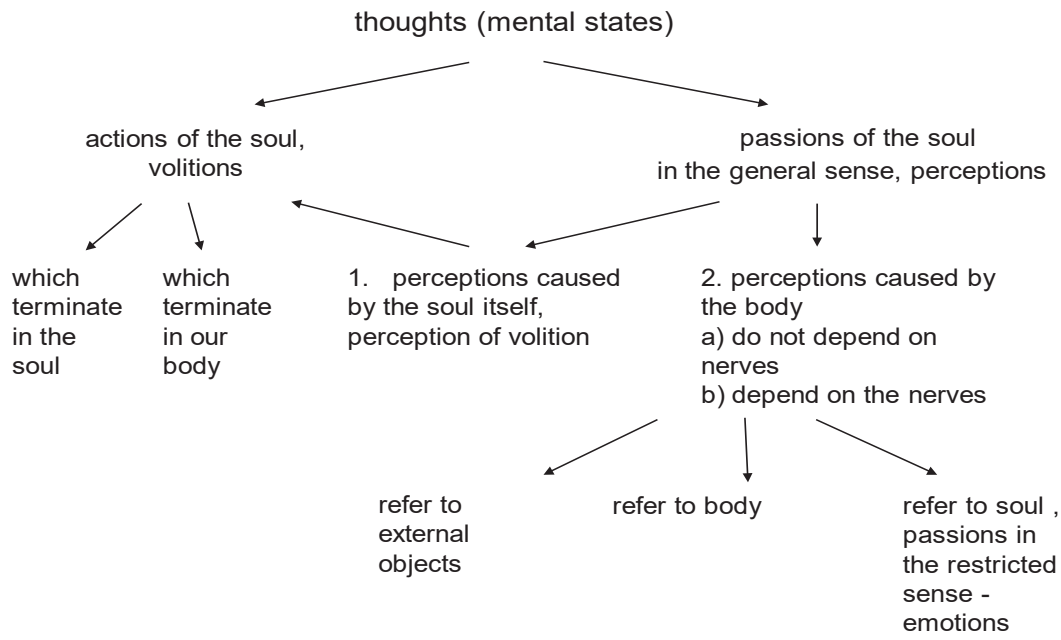

What the diagram shows is that, first, emotions - according to Descartes - belong to the states of the soul, and not the body. Hence, they are thoughts, which means that they are cognitive representations, although 
they are a special sort of representations. Secondly, the division suggests very clearly that emotions are states that find us passive - it is not us who make them as they are (see: Passions 41, CSM I: 343; AT XI 342). What is important here is that emotions are passive states of the soul in the sense that we are not their creators. This is not equivalent to the statement that they are passive in every respect and should be treated as 'an after-thought or epiphenomenon to the basic causal nexus from perception to bodily reaction and purposive action' ${ }^{12}$ As a matter of fact, Descartes stresses the fact that among all the thoughts that can be possessed by the soul these are emotions that may exert the most powerful impact on human behavior (see: Passions 28, CSM I: 339; AT XI 350). It is in part a consequence of the Cartesian thesis that 'any subject which acts more directly upon our soul than the body to which it is joined" (Passions 2, CSM I: 328; AT XI 328). This is why - and Descartes explains this subsequently in article 2 - emotion contains action if the body is considered and it contains passion if the soul is considered. 'Consequently we should recognize that what is passion in the soul is usually an action in the body (Passions 2, CSM I: 328; AT XI 328). ${ }^{13}$

\section{3}

Another important element of the Cartesian theory of emotions is connected with their nature and causes. According to Descartes, external objects are, most usually, the remote cause of emotions (see Passions 51, CSM I: 349; AT XI 371), their proximate cause being some movement of the animal spirits. By the notion of 'animal spirits' he understood the most subtle blood elements that are the only ones able to penetrate the brain. As he wrote:

After having considered in what respects the passions of the soul differ from all its other thoughts, it seems to me that we may define them generally as the perceptions, feelings, or emotions of the soul which we refer particularly to it, and which are caused, maintained, and strengthened by some movement of the spirits (Passions 27, CSM I: 339; AT XI 349; see also Letter to Elisabeth, 6 October 1645, CSMK III: 271)

Taking into account only the above quotations, one could conclude that the Cartesian doctrine of emotion describes emotions as the effects of purely physiological changes. Consequently, what is referred to in

12 William Lyons, Emotion, Cambridge: Cambridge University Press, 1980, 4-5; Desmond Clarke, Descartes's Theory of Mind, $124 \mathrm{ff}$.

13 Paul Hoffman, "The Union and Interaction of Mind and Body," in J. Broughton and J. Carriero (eds.), A Companion to Descartes, Malden: Blackwell, 2008, $400 \mathrm{ff}$. 
Descartes' papers as the sphere of the states of the soul, should in fact be understood as belonging to the bodily realm. But such a view cannot be maintained. In articles 36 and 52 Descartes writes that emotions, although they arise due to bodily changes, have a cognitive factor at their basis as well, and this factor is responsible for our ability to discern between them. Firstly, it enables us to recognize the situations that give rise to emotions; secondly, it enables us to control our emotional states, and - what is most notable in the discussion on causes of emotions - that they cannot arise if unmediated by cognitive processes just as they cannot appear without causes of physiological nature (Passions 51, 52, CSM I: 349; AT XI 371, 372).

Having said that, one is justified in concluding that for Descartes two factors play the key role in evoking emotions:

a) the physiological factor ('the ultimate and most proximate cause of the passions of the soul is simply the agitation by which the spirits move the little gland in the middle of the brain' (Passions 51, CSM I: 349; AT XI 371).

b) the cognitive factor ('I observe, moreover, that the objects which stimulate the senses do not excite different passions in us because of differences in the objects, but only because of the various ways in which they may harm or benefit us, or in general have importance for us' Passions 52, CSM I: 349; AT XI 372).

Because emotions have a physiological factor as their cause on the one hand and a mental factor on the other, they are 'confused and obscure thoughts', thoughts that are not available in a clear and distinct way - in opposition to thoughts whose existence is independent of the mind-body relation (see Passions 28, CSM I: 339; AT XI 350). Our cognition of emotions will never achieve this degree of certainty which characterizes statements of mathematics or some areas of physics. Obviously, we are able to learn something about the corporeal aspect as well as the mental aspect of our emotionality - in a clear and distinct way. But this does not suffice to say that we can gain full knowledge of our emotions. To do this, we would have to have clear and distinct knowledge of the relationship between the body and mind and this is impossible. Besides, as Descartes stressed in his article 51 of the Passions of the Soul, emotions depend on factors beyond one's control as well as on a person's temper. This does not mean, however, that emotions are false judgments in the light of the Cartesian doctrine - as is the case for example in the light of Stoic teachings ${ }^{14}$. Emotions, being 'obscure thoughts', are still thoughts of which we may acquire knowledge that enables us to detect their causes and discern between good and bad elements internal to our emotions.

14 See: Alanen, Descartes's Concept of Mind, 172. 
According to Descartes, the physiological and cognitive factors do not fully account for emotions. Two more factors need to be considered. Firstly, according to the author of Meditations, an inclination towards a certain pattern of behaviour is also a very distinctive factor of emotions. This tendency is not merely an effect of feeling a certain emotion, but something internal to our emotionality (fear is a desire of escape, love is a tendency to unite with the beloved object by volition etc.). Secondly, every emotion is - according to Descartes - accompanied by a certain external signs, e.g. eye movements, blushing, rapid movement of arms and legs or sweating. Let us consider the following example provided by Descartes himself.

There is, say, a wild boar approaching us and it is an object that appeals to our sensory organs - eyes and ears. They send perceptional impulses that are transported via nerves to the pineal gland, located in the center of the brain, where they penetrate each other, creating an image of the object. The pineal gland influences the soul via animal spirits that surround it and convey the image of the object to the soul which receives it as a perception of its own. In order to create the emotional component, the pineal gland must send additional signals via animal spirits which cause bodily changes in the heart, the stomach, and other parts of the body which, in turn, mobilize the body to introduce changes that make it ready to act. At the same time, the perception of the object's image has to be judged as relevant for the perceiver, adequately to the way in which it may do harm or good or be in any way important for the person who experiences it. If the perception of the object does not correlate with the bodily changes and the tendency to act, and the object does not seem significant to the perceiver, no emotion will arise, as it is not a mere awareness of the object that is according to Descartes responsible for evoking an emotion (Passions 52, CSM I: 349; AT XI 372).

Hence, there are four rudimentary factors that are involved in the rise of emotions: 1) physiological changes in different body parts (heart, stomach, lungs); 2) assessment of the object in which the subject is interested and on which the subject's wellbeing depends; 3) type of behavioural reaction to the object; 4 ) bodily expression characteristic of a given emotion (movements of the eyes, nose, lips; frowning of the forehead, changes in the colouring of the face, trembling, laughter, tears, moaning, sighing).

\section{4}

Another issue scrutinized by Descartes is closely connected with the question whether there is something like primitive emotions and, if so, what are they. Answering these questions, Descartes points out yet 
again that the reality of emotions cannot be captured in precise notions and statements. Next, he argues that all emotions can be reduced to six primitive and primeval emotions. These include: wonder/astonishment, love, hatred, desire, joy, and sadness. They give rise to all other kinds of emotions. Referring back to what was stated earlier, it can be said that every primitive emotion can be characterized by four factors: 1) physiological changes; 2) assessment of the object; 3) type of behavioural reaction; 4) bodily expression. These are Descartes' definitions of the six primitive emotions:

\begin{abstract}
"Wonder is a sudden surprise of the soul which brings it to consider with attention the object that seems to it unusual and extraordinary" (Passions 70, CSM I: 353; AT XI 380).

"Love is an emotion of the soul caused by a movement of the spirits, which impels the soul to join itself willingly to objects that appear to be agreeable to it. And hatred is an emotion caused by the spirits, which impels the soul to want to be separated from objects which are presented to it as harmful" (Passions 79, CSM I: 356; AT XI 387).

"The passion of desire is an agitation of the soul caused by spirits which disposes the soul to wish, in the future, for the things it represents to itself as agreeable" (Passions 86, CSM I: 358; AT XI 392).

"Joy is a pleasant emotion which the soul has when it enjoys a good which impressions in the brain represent to it as its own" (Passions 91, CSM I: 360; AT XI 396).

"Sadness is an unpleasant listlessness which affects the soul when it suffers discomfort from an evil or deficiency which impressions in the brain represent to it as its own" (Passions 92, CSM I: 361; AT XI 397).
\end{abstract}

Wonder is, according to Descartes, a very peculiar emotion. What is the basis of the experience of this emotion? Descartes answers: in cognitive terms that will be assessing a given object as something new or outstanding, very different from what one has expected or has so far experienced. If the object is not outstanding from one's point of view, then one does not feel astonished and can reflect on the object emotionlessly. The criterion of judgment is not propriety in this case, but incredibility.

Physiologically, wonder is caused by an impression that has arisen in the brain and animal spirits influenced by this impression and thus powerfully struggling to reinforce and conserve them. The peculiarity of this emotion consists mainly in that it is not accompanied by any bodily changes as it happens with other emotions. That is because the criterion for the assessment is not being good or bad, but only cognition of the object that is the source of wonder/astonishment. It is connected only with the brain where the sensation organs lie. Briefly speaking, the physiological aspect of the emotion of astonishment consists in an increased activity of the brain. As regards the basic mechanism of the reaction, it entails 
a sustained concentration on a given object or situation. As regards the symptoms, this emotion may be accompanied by movements of the face, forehead, and eyes as well as motionlessness of the body.

Next, Descartes argues that wonder is powerful because of the element of surprise and the unexpected appearance of sensations caused by spirits. Surprise is characteristic of this emotion. Its strength depends on two things: a) novelty, b) the fact that the movement of animal spirits from the beginning has its maximum power. What is more, Descartes maintains that new things tease the brain in the areas that are not used to being teased and hence these areas are more delicate and soft, which reinforces the movement of animal spirits. Astonishment is an intense form of wonder. Because it involves an excess of wonder, it is always a bad emotion.

Descartes emphasizes that wonder serves the purpose of recognizing things. It influences the management of attention. That is why "people who are not naturally inclined to wonder are usually very ignorant" (Passions 75, CSM I: 355; AT XI 384). Wonder is not without its drawbacks either. It is better to substitute it with willpower. Who has the tendency to wonder? According to Descartes, these are people who do not lack common sense, but they do lack self-confidence. Conversely, lack of the tendency to wonder characterizes people who are dull or stupid or, on the contrary, the wisest. Esteem and contempt are kinds of wonder experienced when the object is found to be great or trivial, respectively. Significantly, esteem and contempt can take many forms, depending on the object of emotion. When all kinds of things, but not people, are involved, wonder takes the form of simple esteem or contempt. But if the emotion concerns oneself, i.e. somebody refers to oneself or one's merit, this emotion changes into generosity or pride, humility or abjectness. When it comes to different people referred to as individuals who may do harm or good to us, then simple esteem turns to veneration and simple contempt becomes scorn. Thus, there are three kinds of esteem and contempt.

Love. In cognitive aspect, the criterion of assessment is whether a certain thing is good (proper) for someone - if so, one feels love; if it is bad or harmful, then one feels hatred. In terms of physiology, love like all other emotions is caused by animal spirits; its bodily effect is pulse stronger than usual though regular pleasant warmth inside the chest, faster digestive processes, which makes love good for health.

As regards typical behavioural pattern, love makes us strive after union with beloved objects by volition. As regards expression, it can cause helplessness if love entails a desire for something that is at the moment beyond one's reach. ${ }^{15}$ Kinds of love. Descartes discerns the so-

15 "For love makes the soul so engrossed in thinking about the loved object that it uses all the spirits in the brain in representing the image of this object, and it stops 
called concupiscent love that desires to possess (it is the love of possessing the object) and benevolent love which desires the object itself (love of the object). He argues, though, that this difference concerns effects of love and not its essence. Other kinds of love include affection, friendship, and devotion. They are discernible in terms of the degree of respect paid to the loved object and to oneself. If one esteems the object of love less than oneself, such love may be called simple affection. Friendship is characterized by equal respect for oneself and the object of one's love, and if one holds the object in higher esteem than oneself, this emotion may be called devotion (see Passions 83, CSM I: 357; AT XI 390).

Hatred. In terms of cognition - the criterion of assessment is goodness or badness of the object evoking the emotion. If a certain object turns out to be bad, i.e. improper for someone, it causes hatred. In terms of physiology, sensations evoked by the object in the brain lead animal spirits toward the stomach muscles that prevent gastric juice from blending with blood, thus closing all gaps that are usually open to their flow. Hatred is accompanied by irregular heart rate, alternately low and high; one feels cold or sometimes dry, and one experiences unpleasant heat inside the chest; one's stomach does not work properly, one tends to vomit, suffer from gastric diseases and bad miasma (see Passions 103, CSM I: 364; AT XI 404). As regards typical behavioural pattern, hatred causes the will to escape and disunite from the object of hatred. In terms of symptoms, hatred involves the movement of face or nose, sometimes groaning or increased mobility. Though hatred is in a direct opposition to love, it cannot be divided into as many kinds as love, as it takes no account of the degree of evil connected with objects one has separated from (see Passions 84, CSM I: 358; AT XI 391). There is a significant difference between hatred of bad and ugly objects which corresponds to the difference between love of good and beautiful objects. Good or bad objects are the objects which are presented by internal sense or reason. Beautiful or ugly objects are presented by external senses, especially sight. Hatred of ugly objects can be called revulsion or aversion.

Desire. This emotion "is an agitation of the soul caused by spirits that disposes the soul to wish [...] for things it represents to itself as agreeable. Thus we desire not only the presence of goods which are absent but also the preservation of those which are present" (Passions 86, CSM I: 358; AT XI 392). In terms of cognition, the criterion of the assessment is, as before, goodness or badness of the object from one's point of view. But this emotion is marked by the future reference. Further, it covers not only the case when one wants to achieve something that is good from one's point of view or avoid something that seems bad, but also

all the movements of the gland which do not serve this purpose" (Passions 120, CSM I: 370; AT XI 417). 
when one wishes to preserve a good one already has. In physiological terms, desire is specific as it moves the heart more powerfully than any other emotion and provides brain with more animal spirits, which then sharpen all sensational perceptions and make all body parts more ready to move (see Passions 101, CSM I: 363; AT XI 403). In terms of reaction, desire makes one want to have things one perceives as good and avoid those one perceives as bad. In terms of symptoms, desire is accompanied by blushing or weakening.

This emotion has no counterpart. According to Descartes, the same kind of motion is involved in the desires to have good things and to avoid bad things. This is why Descartes rejects the classical conception of desire as emotion which consists in the tendency of striving after good things, with counterpart of aversion, which is the tendency of avoiding bad things (see Passions 88, CSM I: 35994; AT XI). Two important kinds of desire are hope and fear. At their basis, in contrast to simple desire, there is an additional assessment of whether satisfaction of the desire is more or less probable. If one is convinced of great chances of satisfying the desire, this gives rise to hope.

Joy. In terms of cognition, joy is derivative from the belief that one possesses a certain good as his or her own. The criterion of assessment is whether the object is good for one or not. But its very core is in one's perception of this object as one's own. In physiological terms, joy makes one's heart rate regular and fast, although not as high and powerful as in the case of love; pleasant warmth can be felt not only inside the chest, but in every body part, circulating there in blood which is on such occasions abundant; sometimes one may feel lack of appetite as digestion may be disturbed (see Passions 99, CSM I: 363; AT XI 402). In terms of reaction, joy stimulates one to enjoy the good. In terms of symptoms, joy makes one's complexion more vivid and healthy, because openings into the heart open wider than usually and blood flows faster to the veins. Joy arising from good is the only real joy; joy arising from evil is affected by scorn. Among kinds of joy, one can find joy caused by the well-being of people one highly appreciates as it is a good thing to see them flourish. Another kind of joy is a joy of benevolence; it gives one internal satisfaction, which is the most pleasant of all emotions. Yet another kind is kindness or gratitude; kindness is a joy of a good thing that one has done to a fellow man or woman; gratitude is the joy of a good that has been done to one by a fellow man or woman.

Sadness. In terms of cognition, sadness is a result of one's conviction that one is in possession of something bad. The assessment focuses on whether the present evil is considered one's own. In physiological terms, in sadness the heart rate is feeble and slow and one feels as if one's heart was squeezed by ties that freeze it with ice, and cold penetrates the whole body. Despite that, one can still feel appetite and be free of any di- 
gestive problems/issues unless hatred combines with sadness. In terms of reaction, sadness evokes a feeling of unpleasantness of whatever is bad or of poverty. In terms of symptoms, it causes one's face to go pale as this emotion narrows the openings of the heart, blood circulates slower and becomes colder and thicker which, in turn, makes it retreat to wider veins that are located closer to the heart, hence leaving the veins of the face. Sometimes, it makes the face thinner and longer. Other symptoms include trembling, tears and sighing. Occasionally, one flushes feeling sadness instead of going pale, which is the effect of other emotions that join/accompany sadness - like desire or love. On occasion, the emotion is also accompanied by laughter, but the laughter is then artificial and insincere. Envy is a variation of sadness which appears when one observes the prosperity of a person who one thinks has no merit; pity appears if a person with merits suffers injustice. Indignation is a kind of sadness one experiences when something bad happens that does not relate to one; anger appears when one is personally involved. Shame is a sadness caused by one's inner evil in present or past, or by the thought about the negative opinion that others may have about one. Regret appears while one thinks about some past good one does not have anymore or about something bad one has done. It is a highly unpleasant emotion.

\section{5}

Another problem Descartes writes about is whether and how we are able to control our emotions. Firstly, he points out that will cannot evoke or suppress emotion by itself. It is impossible to make a certain emotion appear or to suppress the one that is unwanted. Despite this, will can influence emotions indirectly, via presenting to the soul objects that are connected with the emotions that one wants to feel or opposite to those one wishes to suppress As Descartes puts it:

For example, in order to arouse boldness and suppress fear in ourselves, it is not sufficient to have volition to do so. We must apply ourselves to consider the reasons, objects, or precedents which persuade us that the danger is not great; that there is always more security in defence than in flight; that we shall gain glory and joy if we conquer, whereas we can expect nothing but regret and shame if we flee and so on (Passions 45, CSM I: 345; AT XI 363).

The fact that we cannot directly evoke or suppress our emotions is explained by Descartes by the reference to his claim that emotions are perceptions caused by animal spirits, accompanied by physiological changes. This is why a certain emotion lasts as long as it is maintained by animal spirits. 
There is one special reason why the soul cannot readily change or suspend its passions, which is what led me to say in my definition [article 27] that the passions are not only caused but also maintained and strengthened by some particular movement of the spirits. The reason is that they are nearly accompanied by some disturbance which takes place in the heart and consequently also throughout the blood and the animal spirits. Until this disturbance ceases they remain present to our mind in the same way as the objects of the senses are present to it while they are acting upon our sense organs. (Passions 45, CSM I: 345; AT XI 363)

It follows, then, that only the movement of animal spirits in some part of the body and relevant physiological reactions that influence the soul are able to evoke or suppress a certain emotion. Mere thought of this emotion cannot fulfill this function. However, in case of a weak emotion, the soul can weaken it with the help of will, when it focuses its attention on something else. But strong emotions are not in any way susceptible to such treatment. Nevertheless, Descartes points out that one may tackle the problem in another way. All one needs to do is identify thoughts associated with certain movements of animal spirits whose activity gives rise to certain emotions. Some of the relations between thoughts and animal spirits' movements are fixed naturally while others are created by the environment as a result of recurrent situations and relevant reactions. What is more, Descartes assumes that, at least to a certain degree, we are able to 'reprogram' the connections between thoughts and movements of animal spirits inside our bodies. It is precisely this vulnerability of 'reprogramming' that makes it possible for human beings to take advantage of the relation between the body and the soul, and it is in this way we differ from animals which are determined to react in a given situation always in the same manner.

It is useful to note here, as already mentioned, that although nature seems to have joined every movement of the gland to certain of our thoughts from the beginning of our life, yet we may join them to others through habit. [...] So when a dog sees a partridge, it is naturally disposed to run towards it; and when it hears a gun fired, the noise naturally impels it to run away. Nevertheless, setters are commonly trained so that the sight of a partridge makes them stop, and the subsequent gun-shot makes them run towards the bird. These things are worth noting in order to encourage each of us to make a point of controlling our passions. For since we are able, with a little effort, to change the movements of the brain in animals devoid of reason, it is evident that we can do so still more effectively in the case of men. Even those who have the weakest souls could acquire absolute mastery over all their passions if we employed ingenuity in training and guiding them. (Passions 50, CSM I: 348; AT XI 369-370) 
It is not the only way of controlling human emotions, though. Descartes claims that will may reject the effects of emotions and stop the body movements induced by them, e.g. when anger would make one raise one's fist ready to hit, will may prevent one from doing that.

The Cartesian doctrine of emotions met with two basic reactions in the philosophy of the $17^{\text {th }}$ and $18^{\text {th }}$ centuries. The first one is the cognitive conception offered by Baruch Spinoza in the second half of the $17^{\text {th }}$ century. According to this doctrine, emotions (affects) are caused by specific cognitive processes. The second one is the $18^{\text {th }}$ century Humean doctrine of "sentiments". Here, the rise of emotions amounts to an activation of subjective sentiments, independent of any cognitive processes.

Spinoza was familiar with Descartes' treatise Passions of the Soul. He appreciated many accurate remarks on emotions (affects). He valued transparency and incisiveness of the Cartesian classification of affects. He agreed with Descartes that affects should not be regarded as negative by nature and that they do not disagree with human nature. He also shared with Descartes the opinion that the previous papers on affects were not strictly speaking scientific and did not provide any exact explanations. Nonetheless, he believed that the Cartesian theory of emotion had several basic drawbacks.

Firstly, Descartes was mistaken when he assumed that bodily issues were the causes of affects, underestimating their mental aspect. ${ }^{16}$ Further, accepting this explanation meant recognizing a causal relation between extension and thinking - but these dimensions, having nothing in common, cannot stand in any relationship to each other. In case of things whose basic attributes are different, any relationship is excluded. Another flaw of Descartes conception, according to Spinoza, was that, if the statement that all emotions are perceptions, and not actions caused by bodily factors was to be accepted, one would also have to conclude that a human being is always passive in his or her emotions. However, the greatest weakness of the Cartesian theory is the assumption that the soul, thanks to its internal will, may effectively control emotions. Spinoza considered these errors as so serious that they could not be corrected without profound changes in the core concept of the nature of affects. ${ }^{17}$

16 In the light of the facts presented above, this aspect of the Spinozian criticism of Descartes is not entirely justified.

17 This is how Spinoza expressed this view in the Preface to part III of Ethics: "Most of those who have written about the Affects, and men's way of living, seem to treat, not of natural things, which follow the common laws of nature, but of things which 
According to Spinoza, every emotion (affect) is both bodily and mental by nature: on the one hand, it exists as affections of the body and, on the other, it exists as the idea (representation) of these affections (see Ethics III, def. 3). As opposed to Descartes, however, Spinoza believed that the two dimensions of emotions, considering the conceptual distinctiveness of extension and thinking, exist independently and cannot influence each other. That is why Spinoza finally concludes that neither of these dimensions of the emotion can be connected with the other or explained by reference to the other (Ethics III, prop. 2). The emotion in so far as it is a mode of body can only be explained in terms of bodily causes; the emotion in so far as it is a mode of thought can only be explained in terms of mental causes.

Every emotion, according to Spinoza is a dynamic process by nature and it involves transitions from one state to another. These transitions can take two directions: from a more to a less powerful one or the other way round. Power in this context should be understood, as Spinoza explains, as the force that is engaged in human struggle to preserve and reinforce one's existence. The force, depending on affect in hand, can be more or less powerful. What is important here is that the dynamics expressed in the transition from one state to another is maintained in the affect in its relation to body as well as in its relation to the soul. And that is why Spinoza concludes that 'the idea of anything that increases or diminishes, aids or restrains, our Body's power of acting, increases or diminishes, aids or restrains, our Mind's power of thinking' (Ethics III, prop. 11).

It is the mental dimension of emotions that is most important. This dimension is, and should be, under scrutiny in the first place. What is most crucial here? It is doubtlessly the Spinozian claim that emotions exist only thanks to ideas. If there were no ideas, there would certainly be no emotions. As he writes: 'There are no modes of thinking, such as love, desire, or whatever is designated by the word affects of the mind, unless there is in the same Individual the idea of the thing loved, desired, etc.' (Ethics II, axiom 3).

are outside nature [...]. It is true that there have been some very distinguished men (to whose work and diligence we confess that we owe much), who have written many admirable things about the right way of living, and given men advice full of prudence. But no one, to my knowledge, has determined the nature and powers of the Affects, nor what, on the other hand, the Mind can do to moderate them. I know, of course, that the celebrated Descartes, although he too believed that the Mind has absolute-power over its own actions, nevertheless sought to explain human Affects through their first causes, and at the same time to show the way by which the Mind can have absolute dominion over its Affects. But in my opinion, he showed nothing but the cleverness of his understanding, as I shall show in the proper place" (491-492). 
Because of this close relation between cognition (the idea) and the emotion, the Spinozian theory of emotions is considered one of cognitive theories. The name refers to the group of doctrines that share the assumption that emotions are intentional and require cognitive processes: presence of judgment, whether positive or negative (given in accordance with one's interests), is a sine qua non condition of emotion. What is worth emphasizing though, is that Spinoza's thesis concerning the cognitive character of emotions seems to be more radical than the contemporary standard version of the cognitive conception of emotions. According to Spinoza, the cognitive character of affects does not only include the belief that affects are mental states and cannot appear without cognitive processes. It seems that Spinoza's thesis goes far beyond that. It says that affects are only representations. What is more, as representations are for Spinoza propositional ideas by nature they can be rationally judged, like all other mental states. Hence, they may be classified as true or false, justified or unjustified, adequate or inadequate etc. And so, it can be said that the love that $X$ has for $Y$ is, according to Spinoza, the $X^{\prime}$ 's idea that this love is beneficial for him or her, and if and only if this thought is a justified judgment, then the $X^{\prime}$ s love for the $Y$ is justified. That is why emotions, if considered in their mental dimension, are only representations. Interestingly, Spinoza discerns also the qualitative character of affects, but it does not go beyond the representational content of idea. ${ }^{18}$

Spinoza was deeply convinced that, thanks to his concept of affect as representation, it is possible to 'build the bridge' between human nature perceived from the cognitive perspective and human nature considered in its affective dimension. If the emotion is indeed connected with cognition and does not oppose human nature, then the view that emotions are irrational by nature and that we remain passive in relation to them cannot be maintained. What is more, Spinoza believed that this theory of emotion showed that the efficiency of the affects' impact on our efforts to preserve existence may be measured according to the same rules that are used to analyze different kinds of cognition. Emotions are indeed more difficult to analyze as they are more variable and much quicker in their activity; nevertheless, in their essence, they can be subjected to the same cognitive tools that are used to examine other aspects of human nature.

As for the general division of emotions, the most important are two of them. One is the division into simple and derivative emotions; the other into passive and active ones. Unlike Descartes, Spinoza believed that there are only three simple emotions: desire (cupiditas), joy (laetitia) and sadness (tristitia). It is important to emphasize, though, that desire is of different status than joy and sadness. This is because desire is the

\footnotetext{
18 Michael Della Rocca, Spinoza, London and New York: Routledge, 2008, 34.
} 
most basic motive of a man to preserve his or her existence. In accordance to what has been said above, all the three simple emotions can be understood, in their mental dimension, as a transition from one idea to another, from one representation of a bodily state to another. As for joy, it is 'a man's passage from a lesser to a greater perfection', sadness is a 'passage from a greater to a lesser perfection'. (Ethics III, 11, footnote, see also Ethics III, chart def., def. 2 i 3), while desire is simply mind's transition from one idea, or representation, to another.

Referring to the division into active and passive affects, it is worth noting that Spinoza believed that emotions that come from adequate ideas can be characterized as active states because they have their source in ourselves. By contrast, those that come from inadequate ideas (imagination) can be described as passive states as they come from outside. With reference to the former, we are active; with reference to the latter we remain passive. The desire to maintain existence, shaped by active affects, is a proof of our power The same desire, when shaped by passive emotions, is a proof of our helplessness. What is more, emotions that are caused by adequate ideas tend to be good for us: they help us preserve our existence and strengthen the force of our activities. Emotions caused by inadequate ideas are by contrast bad - they disturb the self-maintenance and diminish our active forces.

Hume shared the Cartesian view that understanding human activity requires recognizing the role played by emotions. He also agreed that the analysis of emotions should take into account conditions in which they appear and their physical manifestation in the human body. Like Descartes, he was deeply convinced that emotions by nature are neither harmful in themselves nor conducive to destructive actions. But, unlike Descartes, he believed that emotions are the only motivation that gets humans out of inertia and makes them act. In particular action, a human being always gives ear to his or her emotions rather than any rationale offered by reason on the basis of certain general principles. It is precisely the emotional aspect of human nature that plays the key role. That is why, as Hume wrote in Treatise of Human Nature, 'reason is and ought to be the slave of the passions, and can never pretend to any other office then to serve and obey them' (T 2,3.3, 415).

According to Hume, emotions are impressions which we recognize in our indirect perception and which cannot be defined, similarly to acts of will or activities. To be more precise, emotions should be perceived (if one is to follow Hume) as reflexive (derivative) impressions, i.e. such that depend on other impressions and ideas. What is most crucial is that emotions do not arise as a result of any cognitive process, but they derive from impressions of pleasure or unpleasantness that are either sensational or not, and they arise either directly or in association with certain ideas. 
As regards Hume's division of emotions, the following three divisions are of crucial importance. Firstly, emotions can be divided into primal and secondary depending on their source. Secondly, they can be divided according to the degree to which they depend on pleasure and pain/distress. Direct emotions arise directly out of pleasure and pain/ distress and include desire, revulsion, sadness, joy, hope, fear, despair, and confidence. Indirect emotions arise when relevant associations of ideas are involved in addition. These emotions include pride and humility, love and hatred. Thirdly, emotions can be divided into calm on the one hand and violent and strong on the other depending on their degree of vividness and force of impact.

All in all, it may be said that in the Cartesian theory of emotions: 1) emotions constitute a separate area of mental states, they differ both from cognitive states and states of the will; 2) all emotions are perceptions of the soul and this is the reason why humans remain passive towards them, as opposed to acts of will in relation to which humans are sometimes active; 3 ) animal spirits that reside in blood and changes occurring in different body parts are the direct cause of emotions; 4 ) there are six simple emotions; 5) every emotion can be considered by reference to, firstly, a certain change in an organism caused by the movement of animal spirits; secondly, their content (cognitive representation of situation); thirdly, a type of behavioural reaction they entail and their specific expression; 6) emotions can only be controlled in an indirect way.

\section{Bibliography}

Alanen, Lilli. Descartes's Concept of Mind. Cambridge, MA: Harvard University Press, 2003.

Cottingham, John. Descartes, Oxford: Blackwell, 1986.

Clarke, Desmond. Descartes's Theory of Mind, Oxford: Oxford University Press, 2005.

Della Rocca, Michael. Spinoza. London and New York: Routledge, 2008.

Descartes, René. The Philosophical Writings of Descartes, translated by R.S.J. Cottingham, D. Murdoch, R. Stoothoff and A. Kenny. Cambridge: Cambridge University Press, 1985-1991, vol. 3.

Descartes, René. The Philosophical Writings of Descartes, translated by J. Cottingham, R. Stoothoff and D. Murdoch, vols. 1 and 2. Cambridge: Cambridge University Press, 1984.

Descartes, René. Oeuvres de Descartes, edited by Charles Adam and Paul Tannery, 12 vols. Paris: Librairie Philosophique J. Vrin, 1996. 
Gaukroger, Stephen. "Descartes' Theory of the Passions." In Descartes, edited by J. Cottingham, 211-24. Oxford: Oxford University Press, 1998.

Le Goff, Jacques. Człowiek średniowiecza. Warszawa-Gdańsk: Wydawnictwo Marabut, 1996.

Hoffman, Paul. "The Union and Interaction of Mind and Body." In: A Companion to Descartes, edited by Janet Broughton and John Carriero, 390403. Malden: Blackwell, 2008.

James, Susan. Passion and Action: The Emotions in Seventeenth-Century Philosophy. Oxford: Oxford University Press, 1997.

Knuuttila, Simo. Emotions in Ancient and Medieval Philosophy. Oxford-New York: Oxford University Press, 2004.

Lyons, William. Emotion. Cambridge: Cambridge University Press, 1980.

Rutherford, Donald (ed.). The Cambridge Companion to Early Modern Philosophy. Cambridge: Cambridge University Press, 2017.

Schmitter, Amy. "How to engineer a human being: passions and functional explanation in Descartes." In A Companion to Descartes, edited by Janet Broughton and John Carriero, 426-44. Malden: Blackwell, 2008.

Shapiro, Lisa. "Descartes' Passions of the Soul and the Union of Mind and Body." Archiv für Geschichte der Philosophie 85, no. 3 (2003): 211-248.

Sorabji, Richard. Emotion and the Peace of Mind: From Stoic Agitation to Christian Temptation. Oxford: Oxford University Press, 2000.

Spinoza, Baruch. "Ethics." In The Collected Works of Spinoza, vol. 1, edited and translated by E. Curley. Princeton: Princeton UP, 1988.

Swieżawski, Stefan. Święty Tomasz na nowo odczytany. Kraków: Znak, 1983.

Vyverberg, Henry. Human Nature, Cultural Diversity, and the French Enlightenment. Oxford-New York: Oxford University Press, 1989.

\section{Summary}

In this paper, I am going to present the Cartesian theory of emotions. The founder of modernity initiated deep changes in the way we understand emotions: their origin and effect on the human being. It is his doctrine of emotions that provided the basis for most discussions on issues concerning emotions in the $17^{\text {th }}$ and $18^{\text {th }}$ centuries and became a reference point for most theories of emotion created in modern times. I attempt, in particular, to make two claims. First, I argue that Descartes' position on the nature of the emotions is best interpreted as something between the physiological theory and the cognitive theory of emotions. Second, I argue that to understand Descartes' account of the genesis of emotions or passions we have to take into consideration four factors: a) physiological changes, e) evaluation of the object, c) behaviour response or action readiness, d) manifestation especially in our facial expression. All those factors are part and parcel of origin of each emotion.

Keywords: Descartes, emotion, passion, Spinoza, Hume 


\section{Streszczenie}

\section{Kartezjańska teoria emocji a filozofia nowożytna}

W niniejszym artykule przedstawiam kartezjańską teorię emocji. Descartes, zapoczątkowujący nowożytność, zainicjował głębokie przemiany w sposobie pojmowania emocji, ich powstawania i skutków. Jego koncepcja emocji dostarczyła podstaw dla siedemnasto- i osiemnastowiecznych dyskusji poświęconych emocjom i stała się punktem odniesienia dla większości nowożytnych teorii emocji. W artykule staram się obronić dwa twierdzenia. Po pierwsze, uważam, że stanowisko Descartes'a w kwestii natury emocji należy interpretować przede wszystkim jako stanowisko pośrednie pomiędzy teorią fizjologiczną emocji a teorią kognitywną. Po drugie, twierdzę, że aby zrozumieć poglądy Descartes'a na pochodzenie emocji czy uczuć, należy wziąć pod uwagę cztery czynniki: a) fizjologiczne zmiany; b) ocenę przedmiotu, c) zachowanie względem przedmiotu bądź gotowość do działania, d) przejawianie się emocji - zwłaszcza w wyrazie twarzy. Wszystkie one stanowią nieodłączny czynnik powstawania każdej emocji.

Słowa kluczowe: Descartes, emocja, uczucia, Spinoza, Hume 